\title{
DEATH PENALTY AND THE RIGHT TO LIFE IN HUMAN RIGHTS PERSPECTIVE, THE 1945 CONSTITUTION OF THE REPUBLIC OF INDONESIA, AND INDONESIAN LAW
}

\author{
Oksidelfa Yanto \\ Master of Law, Universitas Pamulang \\ Email: oksidelfayanto@yahoo.co.id
}

\begin{abstract}
The execution of Death penalty in Indonesia is based on the court verdict that has had a permanent legal power. Only through the court ruling a man can be executed a death penalty upon the guilty alleged at him/her. The death penalty application in Indonesia is provided in the positive law with specific or general nature. As a country having the most verdicts with the capital punishment, either to its local citizen or to the foreign citizen who commits any offenders in the jurisdiction of Republic of Indonesia, triggering the existing of pro and contra stance on the capital punishment execution. The opposing stance based its argument on the human rights perspective, affirming that the capital punishment can be categorized as a form of savage and inhuman punishment and is in the contrary with the constitution. While the stance supporting the capital punishment execution is based on the argumentation that the perpetrator must be avenged in compliance with his/her commit, in order to give a deterrent effect for others who want to commit similar offense. Nevertheless as a matter of fact, there are still many similar offense occurred though capital punishment has been implemented.
\end{abstract}

Keywords : Capital punishment, rights to live and human rights.

\section{A. Introduction}

No one knows on since when the death penalty was held in Indonesia. However, the death penalty has been carried out since centuries years ago in various parts of the world. In Indonesia, the death penalty is known through provision of positive law in Indonesia which is based on Wetboek van Strafrecht were endorsed as the Penal Code by the Dutch government on January 1, 1918. Article I of the Transitional Provisions The 1945 Constitution of The Republic of Indonesia, a milestone in the implementation of Penal Code. In the article I stated all the legislation that is still valid until the new has not held according to the 1945 Constitution of the Republic of Indonesia and strengthened by The Law Number 1 of 1946 on the imposition of the Wetboek van Strafrecht into the Criminal Code. (Read Law Number 1 of 1946 on Criminal Code, Gazette-State Number 127 of 1958). 
Although the existence of the death penalty has been stipulated in the legislation, but the existence always lead to disagreement among the people of Indonesia. Every execution of the death penalty was also a controversy. Anyone agrees and some have refused. They, who agreed that perpetrators of serious crimes deserve the death penalty to be a deterrent effect. While that does not agree with the death penalty argue that the death penalty is contrary to the constitution and the principles of Human Rights (HAM), where each person has the right to life and only God can take the lives of human beings, instead a State. Cesare Marchese di Beccaria once wrote an essay "Dei Delittie Delle Pene" (Of Crimes and Punishments) to the issue of capital punishment. In his essay, Cesare stated that the State has no right to take the lives of people. (Cesare Marchese Di Cesare Beccaria, 1996: 52-53).

Disagreement in the execution at least once sticking at the time of execution Freddy Budiman, the drug kingpin. Executions in Freddy Budiman has provoked a polemic between the pros and cons. In the context of the rule of law, the execution of Freddy Budiman shows the seriousness of the government of President Joko Widodo in law enforcement narcotics cases. Moreover, the death penalty to be a part of the positive law of Indonesia, therefore still valid to be implemented. However, on the other side, people opinion that death penalty is contradicted with the second amendment of the Constitution of The Republic of Indonesia on Article $28 \mathrm{~A}$, Article 28 I clause 1, Article $28 \mathrm{~J}$ clause 1; and the Law Number 39 of 1999 on Human Rights on Article 9 clause 1.

Researcher of Setara Institute, Achmad Fanani Rosyidi evaluated the implementation of the death penalty as a violation of Human Rights (HAM) and therefore must be stopped. According Fanani, the execution of the death penalty is inhuman punishment and violate the norms of human rights. Even in developed countries and pro democracy such punishment is already becoming obsolete. Meanwhile, Vice Chairman of the Executive Board of the National Anti-narcotics Movement (Granat), Asharr Suryobroto said the grenade remained consistent that a death sentence for prisoners who have inkracht, an integral part of the criminal justice system to do. (Http://www.indeksberita.com/pro-kontra-hukuman-mati).

Long before Freddy Budiman case, the statement on the death penalty has been a debate among the community. This became a hot topic in societies ranging 
from academics, practitioners, employees, religious leaders, political party leaders, students and even those who work the informal sector though. The death penalty was also discussed in the spaces discussions, seminars and workshops. Indeed, the death penalty has caused a prolonged debate among the nation.

A law professor, Prof. M. Laica Marzuki said he disagreed with death penalty. Not only against defendants in drug cases, but in all forms of crimes; including the most sadistic murder once (such as genocide). This opinion is supported by Ifdhal Kasim, of the National Human Rights Commission, who said that although the death penalty applies in the United States, in this case the Indonesian people should not imitate the Americans. (Https://abisyakir.wordpress.com/tag/ifdhal-kasim).

From the description above, this study will formulate the problem in two ways. First, what kind of crime that can be punishable by death penalty, as such it is still relevant to the study of positive law implemented in Indonesia? Second, how the implementation of the death penalty in terms of the right to life in Article 28A, Article 28I paragraph 1 and Article 28j paragraph 1 Amendment 2 the 1945 Constitution of the Republic of Indonesia and Article 9 paragraph (1) of Law Number 39 of 1999 on Human Rights.

\section{B. Research Methods}

In this research, the author is using normative legal research conducted by examining secondary data in the form of literature. Secondary data include primary legal materials consisting of the 1945 Constitution of the Republic of Indonesia, legislation in the field of Human Rights (HAM), The Criminal Law Code and regulations related to the provision of capital punishment. While the secondary law consists of literature that support this kind of data research journals, books and research. Data obtained in this paper are qualitative. In such, the analysis in this paper is qualitative data analysis with statute approach, because things that will be examined are various laws that are focus of the problem. Furthermore, the data will be analyzed in a systematic, logical and juridical to generate answers of the problems studied. 


\section{Results and Discussion}

\section{Crimes That Can be Punish by Death Penalty}

Judging from the qualifications, it is a crime under the Criminal Code and some specific law that carries the death penalty is a crime that qualified as serious crimes. Every serious offenders sentenced in accordance with the existing criminal law. Enforcement of the death penalty in Indonesia still refers to the Criminal Code which is a legacy of the Dutch colonial. According to Article 11 of the Criminal Code, the death penalty is executed by way of the gallows noose hangers on the convict's neck, then dropped the plank convicted executioner standing. Since the Japanese occupation of Indonesia, through Stablaad 1945 Number 123, the death penalty is executed by the shooting dead convict, it is then reinforced by Law Number 2 / PNPS / 1964, the State Gazette of 1964 Number 83, (enacted into Law number 5 of 1969) which stipulates that the implementation of capital punishment changed by being shot dead. (Denny Latumaerissa, 2014: 14)

Among the crimes that carry the death sentence in the provision of positive law in Indonesia, both contained in the provisions contained in the general and specific provisions are as follows;

First, the plot to kill the head of state. Article 104 of the Criminal Code states; "Makar with the intent to kill the president and vice president, or with the intent of depriving their independence or make them not able to govern, punishable by death or life imprisonment or criminal for a certain time, the longest twenty years."

In this article, the intent of treason is done with the purpose of life or freedom would eliminate the President and the Vice President or with a view to making them unable to govern properly.

Second, encourage or incite other countries to attack Indonesia. Article 111 of the Criminal Code states; "Whoever contacts with foreign countries, with a king or tribe with the intent of arousing it to commit acts of hostility or war against the state, or reinforce the intention to, or pledged in the act, or help prepare the act shall be punishable with imprisonment fifteen years. "" If hostilities or war; it's punishable by death or life imprisonment or imprisonment for a certain period of time a maximum of twenty years. " 
Third, to protect or help an enemy that fought against Indonesia. Article 124 (3) Criminal Code states; "Criminal death or imprisonment for life or for a certain period of time a maximum of twenty years imposed if the creator: notify or surrender to the enemy, destroying or damaging something or post a reinforced or occupied, an interface, warehouse inventories of war, or war cash or navy, army or any part thereof; hinder, obstruct or thwart an attempt to inundate water or other military efforts planned or organized to parry or attack; cause or accelerate the onset of insurrection, mutiny or desertion among the armed forces. "

Fourth, the murder was planned in advance. Article 340 of the Criminal Code states; "Those who deliberately and with a plan in advance depriving another person's life, threatened due to the assassination plan, with the death penalty or life imprisonment or for a certain time, a maximum of twenty years."

As such, murder is murder committed by a defendant with premeditation, for example, by negotiating with others or after thinking about tactics that will be used to carry out his evil intentions with profusely in advance, before the cruel acts that commencement. (Djoko Prakoso and Nurwachid, 1984: 34).

Fifth, theft with violence allied result in severe injury or death. Article 365 of the Cirminal Code states; (1) "Threatened with maximum imprisonment of nine years, the theft which preceded, accompanied or followed by violence or threat of violence, against people, with a view to mempersiap or facilitate theft, or in the case caught redhanded, to allow the escape itself or participants the other, or to keep control of the stolen goods. (2) "If the act results in death, it is subject to a maximum imprisonment of fifteen years." (3) "Threatened with death penalty or imprisonment for life or for a certain time not later than twenty years, if the act results in serious injury or death and carried out by two or more persons with allied, also accompanied by one of the points described in numbers 1 and 3."

Definition of serious injuries, namely as defined in Article 90 of the Criminal Code, is :

a. falls ill or gets injured that does not give hope will be cured at all, or that pose a danger of death,

b. not being able constantly to run errands office or employment income, 

c. lose one senses,
d. got severe disabilities (verminking),
e. suffering from paralysis,
f. disruption of the power of thought for four weeks or more,
g. the death or the death of a woman's womb.

Seventh, piracy at sea resulted in the deaths. Article 444 states; "If the acts of violence that is applied in articles 438-441 lead someone on board who attacked or assaulted someone who was dead, the captain, the commander or leader board and they were involved in the act of violence, threatened with capital punishment, life imprisonment, or imprisonment for a certain period of time a maximum of twenty years. "

Ninth, regarding narcotics crimes. Article 80 (1) of Law Number 35 Year 2009 on Narcotics mention; (1) "Whosoever without any right or illegally: produce, process, extract, convert, assemble, or providing narcotics Category I, shall be punished with death or imprisonment for life, or imprisonment for a period of 20 (twenty) years and a maximum fine of Rp. 1,000,000,000.00 (one billion rupiah); (2) When the offenses referred to in paragraph (1) letter a is preceded by a conspiracy, punishable by death or life imprisonment or imprisonment of at least 4 (four) years and a maximum of 20 (twenty) years and a fine bit Rp. 200,000,000.00 (two hundred million rupiah) and Rp. 2,000,000,000.00 (two billion rupiah); (3) When the offenses referred to in paragraph (1) letter a is done in an organized manner, shall be punished with death or imprisonment for life or a term of imprisonment of five (5) years and a maximum of 20 (twenty) years and a fine bit Rp. 500,000,000.00 (five hundred million rupiah); and most Rp.5.000.000.000,00 (five billion rupiah).

Article 81 of Law Number 35 of 2009 on Narcotics mention; (1) "Whoever without rights and against the law; a. carrying, transfer, transport, or mentransito Schedule I narcotics, shall be punished with imprisonment for a period of 15 (fifteen) years and a maximum fine of Rp. 750,000,000.00 (seven hundred and fifty million rupiah); (3) When the offenses referred to in, paragraph (1) letter a is done in an organized manner, shall be punished with death or imprisonment for life, or 
imprisonment for a minimum of 4 (four) years and a maximum of 20 (twenty) years and a minimum fine of Rp. 500,000,000.00 (five hundred million rupiah) and Rp. 4,000,000,000.00 (four billion rupiah); "

Article 82 of Law Number 35 of 2009 on Narcotics mention; (1) "Whosoever without any right or illegally: a. importing, exporting, offering for sale, distributes, sells, buys, delivers, be an intermediary in the sale and purchase, the tool exchanging narcotics Category I, shall be punished with death or imprisonment for life, or imprisonment for life, or imprisonment for a 20 (twenty) years and a maximum fine of RP. 1,000,000,000.00 (one miyar rupiah); (2) When the offenses referred to in paragraph (1) is preceded by a conspiracy, then the offenses referred to in: a. paragraph (1) letter a, shall be punished by death or life imprisonment or imprisonment for a minimum of 4 (four) years and a maximum of 20 (twenty) years and a fine of at least Rp. 200,000,000.00 (two hundred million rupiah) and Rp. 2,000,000,000.00 (two miyar rupiah); (3) When the offenses referred to in: a. paragraph (1) letter a is done in an organized manner, shall be punished with death, or imprisonment for life, or a term of imprisonment of five (5) years and a maximum of 20 (twenty) years and a fine of at least Rp. 500,000,000.00 (five hundred million rupiah) and Rp. 3,000,000,000.00 (three billion rupiah). "

Tenth, the Law Number 20 of 2001 on Corruption, Article 2 of Law Number 20 of 2001 on the Corruption mention; (1) Any person who acts unlawfully enrich themselves or another person or a corporation that can be detrimental to the state finance or economy of the state, shall be punished with imprisonment for life or imprisonment for a minimum of 4 (four) years and a maximum of 20 ( twenty) years and a fine of at least Rp 200,000,000.00 (two hundred million rupiah) and at most Rp $1,000,000,000.00$ (one billion rupiah). (2) In the case of corruption as referred to in paragraph (1) shall be done in certain circumstances, the death penalty can be imposed. About Corruption in Article 2, paragraph 2 a criminal offense aggravated criminal threat, which if a criminal act is done in certain circumstances it is against such offenses may be subject to the death penalty. The terminology used in certain circumstances here if corruption is done while the country was in danger, in times of national disasters and at the time of a state of economic and monetary crisis. 
Eleventh, Law Number 26 of 2000 on Human Rights Court. Article 8 states : The crime of genocide as defined in Article 7 letter a is any act committed with intent to destroy or annihilate whole or in part the group of nations, races, ethnic groups, religious groups, by the way:

a. killing members of the group;

b. resulting in serious bodily or mental harm to members of the group;

c. created the group conditions of life will lead to annihilation physically whole or in part;

d. imposing measures intended to prevent births within the group; or

e. forcibly transferring children of the group to another group.

Article 9 of Law Number 26 of 2000 on Human Rights Court mentioned; "Crimes against humanity as referred to in Article 7 letter $b$ is one of the following acts when committed as part of a widespread or systematic attack with the knowledge that such attack directed against any civilian population, such as:

a. murder;

b. extermination;

c. slavery;

d. expulsion or forcible transfer of population;

e. deprivation of freedom or other physical freedom arbitrary abuse (principles) basic provisions of international law;

f. torture;

g. rape, sexual slavery, enforced prostitution, forced pregnancy, enforced sterilization or sterilization or other forms of sexual violence of similar;

h. persecution of a particular group or association that is based on equality political opinion, race, nationality, ethnicity, culture, religion, gender or other grounds that are universally recognized as impermissible under international law;

i. enforced disappearances; or

j. the crime of apartheid. "

Article 36 of Law Number 26 of 2000 on Human Rights Court mentioned; "Anyone who commits acts as referred to in Article 8 letter a, b, c, d, or e punishable by death or imprisonment for life or imprisonment for a period of 25 (twenty five) years and at least 10 (ten) year." Article 37 of Law Number 26 of 2000 on Human 
Rights Court mentioned; "Anyone who commits acts as referred to in Article $9 \mathrm{a}, \mathrm{b}, \mathrm{d}$, $\mathrm{e}$, or $\mathrm{j}$ shall be punished with death or imprisonment for life or imprisonment for a period of 25 (twenty five) years and at least 10 (ten) year."

Twelfth, Law Number 15 of 2003 on Government Regulation Number 1 of 2002 on Combating Criminal Acts of Terrorism into law regulation. Article 6 states; "Any person who deliberately uses violence or threat of violence lead to an atmosphere of terror or fear of the widespread or cause the victim that is massive, by robbing the independence or the loss of life and property of others, or cause damage or destruction of the objects vital strategic or environmental or public facilities or international facilities, shall be punished with death or imprisonment for life or imprisonment for a minimum of 4 (four) lahun and a maximum of 20 (twenty) years."

Article 9 states; "Any person who unlawfully enter into Indonesia, creating, receiving, trying to obtain, submit or attempt to deliver, master, carry, have a supply to him, or has in his, storing, transporting, menyem-ring, use, or pull out of Indonesia something firearms, ammunition, explosives or something, with intent to commit criminal acts of terrorism, shall be punished with death or imprisonment for life or a term of imprisonment of 3 (three) years and a maximum of 20 (twenty) years. "

Article 10 states; "Punishable by the same criminal with the crime referred to in Article 6, any person who knowingly using chemical, biological weapons, radiological, microorganisms, radio-active or components, causing an atmosphere of terror, or a fear of widespread, inflicting casualties is massive, harmful to health, there is chaos on the lives, safety, and rights of people, or damage to, destruction of the objects of vital strategic, environmental, public facilities, or international facilities. "

Article 14 mentions; "Everyone who plan and / or mobilizing others to commit criminal acts of terrorism as referred to in Article 6, Article 7, Article 8, Article 9, Article 10, Article II and Article 12 shall be punished by death or life imprisonment." Thirteenth, Act No. 23 of 2002 on Child Protection. Article 89 paragraph 1 states; "Any person who knowingly placing, allowing, involving, told engage in child abuse, production or distribution of narcotic drugs and / or psychotropic substances shall be punished with death or imprisonment for life or imprisonment for a period of 20 
(twenty) years and a maximum imprisonment 5 (five) years and a maximum fine of Rp 500,000,000.00 (five hundred million rupiah) and at least US \$ 50,000,000.00 (fifty million rupiah). "

Fourteenth, Emergency Law Number 12 of 1951 on firearms, ammunition or something explosives. Article 1, paragraph 1 states; "Whoever, without the right to enter into Indonesia, creating, receiving, trying to obtain, submit or attempt to deliver, master, carry, have a supply to him, or has in his, storing, transporting, concealing, use or release of Indonesian something firearms, ammunition or something explosives, punishable by death or life imprisonment or imprisonment while the maximum of twenty years. "

From provisions governing the death penalty for crimes above, it is clear that Indonesia is one of the countries that still apply the death penalty threat to the system of criminal law over certain crimes as contained in the articles above. It at least has been confirmed explicitly in article 10 of the Criminal Code and several law as the law applicable in the entire territory of Indonesia. Even provisions regarding capital punishment is also known almost by all the tribes in Indonesia. Various kinds of offense committed punishable by death. How to carry out the death penalty is also diverse, stabbed with a dagger, drowned, dried under the sun until death, his head pounded with a pestle and others. (Andi Hamzah, 1984: 47).

Implementation of the death penalty from the above provisions had been implemented in law enforcement Indonesia. Call it like execution of the drug lord Freddy Budiman in 2016. Even long before or around 2008 the death sentence has also been imposed on the perpetrators of criminal acts of terrorism Amrozi's group in the Bali bombings. In the case of murder, the state has also been executing Achmad Suradji for murdering 42 women in 2008 in North Sumatra.

In applying the types of punishment in the Criminal Code and some specific law, the death penalty is a punishment most feared of the humanitarian side of the offender. In countries that still apply the death penalty, its application addressed to the perpetrators of the most heinous. Indonesia was also impose the death penalty for crimes that are very cruel, as in the case of murder. Perpetrators sometimes very cruel 
and depriving a person's life. No wonder then the culprit was also punished so severely, because forcibly deprived of his life.

That the implementation of the death penalty is deprivation of human life is something that can be justified in the context of when a person sentenced to death were executed. When the firing squad executes the terampaslah right to life for him. When the death penalty has been carried out already clearly can no longer give hope someone convicted to repent and improve. Yet in reality the death penalty has not been able to be a deterrent for someone to not do evil.

Some philosophical view of punishment or criminal purposes as a form of reprisal and providers fear or deterrent effect for others not to commit similar crimes in the future. Seeing the practice of execution of capital punishment in the United Kingdom, at which time the crowd gathered to watch the hanging of the thief, pickpocket others instead used the opportunity to fondle the pockets of the audience, gave birth to doubts as to whether the application of the death penalty will make people afraid or even more courage to commit crime. The practice of the death penalty is also often considered to be biased, especially the class bias and racial bias. In the United States, approximately $80 \%$ of death row inmates are non-white and come from the lower classes. While in many countries many death row inmate who is a foreign citizen but was not given an interpreter during the trial process. (Mohammed, 2011: vii -viii).

The birth of the science of criminology as scientific knowledge is one motivated by a sense of dissatisfaction on the implementation of the criminal justice system. The method of implementation of criminal law at that time (16th -18 th century) is expected to provide protection and security to society by giving severe sanctions against any offender, turned out to be ineffective. Criminal law conducted solely scare by giving severe sanctions. (Amrizal Siagian, 2013: 8).

During this time the punishment of offenders is more oriented to retaliation is the purpose of the sentencing. In the theory of absolute or retaliation someone should be paid for the crimes he had done. According to this absolute theory, every crime should be followed by a criminal, may not be so, without bargaining. One gets pidanapun for having committed a crime. Not seen any consequences that might arise as a result of this criminal punishment. This theory was impressed retaliation 
(vergelding) by a lot of people put forward as a reason to penalize the crime. Satisfaction pursued careful, otherwise nothing. (Wirjono prodjodikoro, 1989: 21).

In its capacity to implement law enforcement oriented values of justice, law enforcement agencies should give priority to humanitarian values paired with the value of justice in addition to the value of legal certainty. Law is no longer merely a procedure to meet the retaliation against the perpetrators. Upholding the values of humanity actually become more meaningful in human rights principles. Although true, important part of the application of criminal sanctions for those who commit crimes.

Criminal prosecution against perpetrators of crimes can not be separated from the criminal system adopted by the legal system in Indonesia. Important part of the criminal system is setting a sanction. Its presence will provide direction and consideration of what sanctions should be used in a criminal act to enforce the enactment of the norm. On the other hand, punishment itself is the most complex processes in the criminal justice system because it involves many different people and institutions. (Puteri Herawati, 2011: 332).

Muladi stated that criminal law should not be oriented only human actions alone (daadstrafrecht), because such criminal law becomes inhuman and prioritize retaliation. Criminal is oriented to the fulfillment of criminal elements in the legislation. (J.E Sahetapy, 2007: 8). The fulfillment of the elements of a criminal offense is the reason sentenced once in a person accused of wrongdoing in court. However, any heavy sentence imposed has not fully eliminate the crime itself. In the imposition of capital punishment, for example, the effect of the death penalty is not fully able to avoid evil. People tend to do evil even though it applied to a sentence of death.

Karl O. Christiansen as quoted by Ibn Subarkah and Lukman Hakim in the Yustisia Journal Edition May to August 92, 2015 suggests the influence offense to the general public is very difficult to measure, in other words the limited ability of the criminal law, among others, can be seen also from the nature / function of punishment 
for this , the criminalization of individual / personal and not punishment structural / functional (Karl O. Christiansen, 1968: 366).

The application of the Criminal Code in the future should pay attention to the values of humanity, especially the chapters fore the death penalty on offenders. Articles of the death penalty to the attention of all parties. Supposedly the articles about the death penalty was replaced with life sentence to death in prison for offenders. Not to impose the death penalty. Because they are not necessarily sentenced to death, the real culprit. Moreover, the application of penalties berated the constitution and principles of human rights should dikedepan in the realm of law, especially criminal law. Policy makers are supposed to think about it. Many ways can be done, for example, with crime prevention.

Crime prevention policy via the non penal is more a precaution before the occurrence of the crime. Therefore, the main goal is dealing with the factors conducive to the cause of the crime centered on a problem or social conditions that directly or indirectly may cause or foster-suburkan crime. Thus, viewed from the crime prevention policy, the efforts of non penal has a strategic position and play a key role which must be intensified and made effective. (Barda Nawawi Arief, 1996: 28). Efforts and policies to create good rules of criminal law in essence can not be removed from the crime prevention goals are guided by the constitution and principles of human rights. Therefore, policies or politics of criminal law is also part of a political crime, so the politics of criminal law is identical to the definition of "crime prevention policies with the criminal law". (M.Hamdan, 1997: 21)

\section{Death Penalty In Perspective Human Rights and the 1945 Constitution}

It is undeniable that the right to life is a gift from God Almighty that has existed since the man in the womb of his mother. Such rights shall be regarded as the highest human rights that must be respected, upheld and protected by anyone, including the state. Contrary to the above view, it would be proper that execution of the death penalty has always been a conversation that is hard to avoid the debate when it will and already implemented, both the cons and the pros. Right to human life as stated in the Universal Declaration of Articles 3 and 5 which guarantees the right of 
people to live to be the reason the debate. Article 3 states that; every person has the right to life, the right to liberty and security of personal self. Article 5 mentions that; "No one shall be subjected to torture or cruel, treated or punished inhumanely or insulted".

Another basic argument is also due to the right to life set forth explicitly in Article 28 A, Article 28, first paragraph 1 Second amendment of the 1945 Constitution Article 28 A of the 1945 Constitution states that: "Everyone has the right to live and to defend life and living". As for the content of Article 28, first paragraph 1 are: "The right to life, freedom from torture, freedom of thought and conscience, freedom of religion, freedom from enslavement, recognition as a person before the law, and the right not to be prosecuted on the basis of retroactive law is a human right that can not be reduced under any circumstances ". While Article $28 \mathrm{~A}$, paragraph 1 of the 1945 Constitution states that: "Every person shall respect the human rights of others in the orderly life of society, nation and country". While Article 9 paragraph (1) of Law Number 39 of 1999 on Human Rights restate that "everyone has the right to life, survival and improve the standard of living".

All of the above article explaining their right to live and to defend life and living, because the right of human life can not be reduced under any circumstances. With the application of capital punishment then the person can not repair itself, can not preserve their life as guaranteed by Law. The law is no longer provides human protections.

The legal protection according to Satjipto Raharjo, which provides shelter for human rights that harmed others and the protection provided to the public in order to enjoy all the rights given by law. (Satjipto Raharjo, 2000: 54). Hamid S. Attamimi argued, the importance of a constitution was as givers and providers limit grip, as well as about how the power of the country should be run. Thus, the Constitution is 'the basic of the national legal order', therefore in each country will find a Constitution, either a 'single document' or 'multi-document'. As 'the basic of the national legal order', then the provisions of the Constitution will be a source of reference for the establishment of state legislation that inferior of the Constitution. (Widodo Ekatjahjana, 2008: 27). 
Asshiddiqie also stated that the Constitution is not the ordinary law. He was not assigned by the ordinary legislature, but by the agency more specialized and higher in social status. If the legal norms contained are contradicted to legal norms contained in the law, then the provisions of the 1945 Constitution should be applied, while the Law must give path to it (it prevails and the ordinary law must give way) (Asshiddiqie, 2008: 5)..

If the execution of the death penalty imposed in various forms of crime, then in hierarchy, it is already a conflict of legislation. Although basically, the legal existence of the most highest in the discipline of law can not be contradicted by regulations that hierarchically lower than the constitution. In such, the existence of human rights must be acknowledged in the constitution.

Thus, the recognition of the right to life that is part of the human rights enshrined in the 1945 Constitution is important to take into account and should not be overlooked. The provisions of the right to life is also in reemphasize in Article 4 of Law Number 39 of 1999 on Human Rights, which set the "right to life, freedom from torture, the right to personal freedom, freedom of thought and conscience, freedom of religion, the right not enslaved, the right to recognition as a person and equality before the law, and not be prosecuted based on retroactive law is a human right that can not be reduced under any circumstances and by anyone ". In other words that all Indonesian people have a right to life that must remain guaranteed by the state. The rights can not be taken away under any circumstances regardless of their race, religion, gender, or social status and the legal status of a person.

The death penalty is clearly depriving the right to life for someone. In the context of legal justice then it is certainly not fair for the benefit of man. Roscoe Pound argued the law is a tool of social engineering. Human interest is a demand that the protection and fulfillment of human in the field of law. (Bernard L. Tanya et al, 2010: 154). When a person has been sentenced to death for his alleged errors, then what is guaranteed in the Constitution into something that does not have any meaning. In practice, it is not an absolute that judge based his faith decide someone alleged, although the evidence submitted. Many verdict does not reflect a sense of justice to convict. 
The verdict did not reflect the rule of law, justice and expediency in the end influence the image of the judiciary. Realizing the judge's decision was based on the rule of law, justice and expediency is not easy, let alone justice. This is due to the concept of justice in the judge's decision is not easy to look for the benchmark. (Fence M wantu, 2007: 391). In the end, the law as man-made products have always had a real weakness. Law is not something that is neutral, so the law inclined or even always have alignments. This is in line with the concept that the law is a product of politics, where the law is regarded as affected variable (dependent variable) and politics as an influential variable (independent variable). (Moh. Mahfud MD, 1998: 2).

Therefore, the law should be understood and developed as a unified system. Moreover, the country was about to be understood as a legal concept, namely as a legal state. In law as a unified system are (1) the elements of institutional / element institutional, (2) the elements kaedah rules / instrumental element, and (3) elements of the behavior of legal subjects who holds the rights and obligations prescribed by the norms that rule / subjective element and cultural. (Asshiddiqie, 2015: 119)

As man-made, then the law is the result of a thought of a human being. Then practiced law with man as the subject. So that it can be said that the law and the human can never be separated. Because the laws of human origin and is run by humans, then the law should also be based on ethics and morals. The law demands how humans behave good. Good behavior will become a norm that must be adhered to. Thus the law is not biased, the law should be neutral, the law impartially and not easily influenced and tend to promote the principles of fairness and certainty.

\section{Conclusion}

Indonesia is a state based on law (rechtsstaat), not based on power alone (machtsstaat). This provision is stipulated in article 1, paragraph 3 of the 1945 Constitution. As a country that is based on the law, then any decisions and policies made by the government should be based on applicable law. Among the laws that apply in Indonesia is a positive law set out in the Criminal Code as lex generalist or a 
common and legislation as a lex specialis. General and specific legal provisions contains sanctions capital punishment to offenders. There are several types of crimes that can be sentenced to the death penalty.

The principle that all crimes must be repaid in accordance with the crimes they have committed are justified in theory of retaliation. Retaliation meant to be a deterrent effect for other actors. One of the deterrent effect of the death penalty is applied. But the execution has not been able to come a deterrent effect. Perpetrators are still flourishing. Here and there the pros and cons of the death penalty is always popping up. Who agree with the death penalty say that the death penalty is the only way to apply justice to the victims. While refusing say the death penalty is contrary to Article 4 of Law Number 39 of 1999 on Human Rights, which set the "right to life". Contrary to Article 9 paragraph (1) of Law Number 39 of 1999 on Human Rights that "everyone has the right to life, survival and improve the standard of living".

In addition, it is also contrary to Article 28 A of the 1945 Constitution which states that everyone has the right to live and to defend life and livelihood. Then it is also contrary to Article 28 I, paragraph 1 of the 1945 Constitution which states the right to life, freedom from torture, freedom of thought and conscience, freedom of religion, freedom from enslavement, recognition as a person before the law, and the right not to be prosecuted on the basis of retroactive laws are human rights that can not be reduced under any circumstances. A final Article 28 paragraph 1 of the 1945 Constitution states Everybody is obliged to respect the human rights of others in the orderly life of society, nation and state. That Articles above, contrasted with the implementation of the death penalty. In view of law, it is not certain that offenders sentenced to death are guilty. Because judges are human beings who are not infallible. Although basically the judge demanded to uphold the values of truth and justice. Case of Sengkon and Karta is proof that the judge was not immune from mistakes. Sengkon verdict 12 years and Karta verdict seven (7) years in prison for a murder case that was never done. After five (5) years serving a sentence, Genul Sengkon nephew admitted that it was he who committed the murder. It is not possible when a death sentence has been carried out so the inmate is convicted is not the real perpetrators of the crime, while the right to life has been taken away through execution. Na'udzubillahimindzalik. 


\section{REFERENCES}

\section{$\underline{\text { Book }}$}

Amrizal Siagian, Pengantar Studi Kriminologi: Perkembangan Pemikiran dan Teori Kriminologi, (Jakarta: UIN Jakarta Press, 2013).

Andi Hamzah, Pidana Mati Di Indonesia: Di Masa lalu, Kini dan Masa Depan, (Jakarta: Ghalia Indonesia, 1984).

Barda Nawawi Arief, Bunga Rampai Kebijakan Hukum Pidana, (Bandung: Citra Adtya Bakti, 1996).

Bernard L. Tanya dkk, Teori Hukum Startegi Tertib Manusia Lintas Ruang dan Generasi, (Yogyakarta: Genta Publishing, 2010).

Cesare Marchese Di Beccaria, Of Crimes and Punishments, (Jane Grigson, Penerjemah), New York: Marsilio, 1996.

Djoko Prakoso dan Nurwachid, Studi tentang pendapat-pendapat mengenai efektivitas Pidana Mati di Indonesia dewasa ini, (Jakarta: Penerbit Ghalia Indonesia, 1984).

Jimly Asshiddiqie, Konstitusi Dan Hak Asasi Manusia, Bahan Lecture Peringatan 10 Tahun Kontras, (Jakarta, 26 Maret 2008).

Konstitus Bernegara: Praksis Kenegaraan Bermartabat dan Demokrasi, (Malang: Setara Press, 2015).

J.E Sahetapy, Pidana Mati Dalam Negara Pancasila,(Bandung: Citra Aditya, 2007).

Karl O Kristiansen, Some Considerans on the Possibility of Rational Criminal Policy”, Resource Material Series No. 7. Tokyo, UNAFEI, Tokyo.

M. Hamdan, Pokok Hukum Pidana, (Jakarta: PT. Raja Grafindo Persada, 1997).

M. Mahfud MD, Politik Hukum di Indonesia, Cet. Pertama, (Jakarta: PT. Pustaka LP3ES Indonesia, 1998).

Satjipto Raharjo, Ilmu Hukum, (Bandung, PT, Citra Aditya, Bakti, 2000).

Widodo Ekatjahjana, Lembaga Kepresidenan dalam Sistem Ketatanegaraan Indonesia, (Bandung: Pustaka Sutra, 2008). 
Wirjono Prodjodikoro, Asas-Asas Hukum Pidana Di Indonesia, (Bandung: Eresco, 1989).

\section{$\underline{\text { Journal }}$}

Ibnu Subarkah dan Lukman Hakim, Penanggulangan Campur Tangan Urusan Peradilan di Luar Kekuasaan Kehakiman Berbasis Penal Reform (Studi Di Wilayah Hukum Pengadilan Tinggi Jawa Timur), Jurnal Hukum Yustisia, Fakultas Hukum Universitas Sebelas Maret, Edisi 92 Mei-Agustus 2015.

Denny Latumaerissa, Tinjauan Yuridis Tentang Penerapan Ancaman Pidana Mati Dalam Tindak Pidana Korupsi, Jurnal Ilmiah "SASI" Fakultas Hukum Universitas Patimura Ambon, Vol. 20 No. 1. Bulan JanuariJuni 2014.

Fence M Wantu, Antinomi Dalam Penegakan Hukum Oleh Hakim, Jurnal Mimbar Hukum, Vol. 19 No. 3, Oktober 2007, Yogyakarta: FH. UGM

Mohammad, Hukuman Mati Dan Hak Asasi Manusia Dalam Peraturan Perundang-Undangan, Jurnal Yustisia, Fakultas Hukum Universitas Madura-Pamekasan, Volume 12, No.1 November, 2011.

Puteri Hikmawati, Analisis Terhadap Sanksi Pidana bagi Pengguna Narkotika, Jurnal Ilmiah Negara Hukum, Sekretariat Jenderal Dewan Perwakilan Rakyat Indonesia, Volume 2 Nomor 2, November Tahun 2011.

\section{$\underline{\text { Legislation Sources }}$}

Undang-Undang Nomor 1 Tahun 1946 Tentang Peraturan Hukum Pidana Untuk Seluruh Wilayah Republik Indonesia/Kitab Undang-Undang Hukum Pidana

Undang-Undang Nomor 20 tahun 2001 Tentang Tindak Pidana Korupsi

Undang-Undang Nomor 15 tahun 2003 Tentang Tindak Pidana Terorisme

Undang-Undang Nomor 23 tahun 2002 tentang Perlindungan Anak

Undang-Undang Nomor 35 Tahun 2009 Tentang Tindak Pidana Narkotika

Undang-Undang Nomor 39 tahun 1999 tentang Hak Asasi Manusia

Undang-Undang Darurat Nomor 12 tahun 1951 tentang Senjata api, amunisi atau sesuatu bahan peledak

\section{Website}


http://www.indeksberita.com/pro-kontra-hukuman-mati/

https://abisyakir.wordpress.com/tag/ifdhal-kasim/ 